\title{
An Effective Procedure for In Vitro Culture of Eleusine coracana (L.) and Its Application
}

\author{
Alla I. Yemets, Galina Ya. Bayer, and Yaroslav B. Blume \\ Institute of Food Biotechnology and Genomics, National Academy of Sciences of Ukraine, Osipovskogo Street 2a, Kiev 04123, Ukraine \\ Correspondence should be addressed to Alla I. Yemets; yemets.alla@gmail.com
}

Received 21 April 2013; Accepted 15 May 2013

Academic Editors: T. Berberich, K. P. Martin, and S. Ogita

Copyright (C) 2013 Alla I. Yemets et al. This is an open access article distributed under the Creative Commons Attribution License, which permits unrestricted use, distribution, and reproduction in any medium, provided the original work is properly cited.

\begin{abstract}
Efficient protocols for callus production, plantlet regeneration, protoplast isolation, and micronucleation of finger millet (Eleusine coracana (L.) Gaertn.) were developed. White nodulated calli were formed on medium with $\mathrm{N}_{6}$ macrosalts, MS microsalts, 2.4dichlorophenoxyacetic acid $\left(2 \mathrm{mg} \mathrm{L}^{-1}\right)$, kinetin $\left(0.4 \mathrm{mg} \mathrm{L}^{-1}\right)$, 1-naphthalene acetic acid $\left(2 \mathrm{mg} \mathrm{L}^{-1}\right)$, and certain additives. It was found that appropriate supplementation leads to formation of numerous shoots. Healthy rooted plantlets formed on hormonefree media. Although different tested additives had no significant effect on percentage of callus formation, it affected callus quality that further dictated plant-forming capacities. Seedlings were better source tissues for protoplasts isolation compared to callus cultures. About $5 \times 10^{6}$ protoplasts were isolated from one gram of seedling coleoptyles. Microcolonies were visible after 20-25 days' incubation on KM8p medium supplemented with glutamine $\left(100 \mathrm{mg} \mathrm{L}^{-1}\right)$ and proline $\left(500 \mathrm{mg} \mathrm{L}^{-1}\right)$. Here we also present a procedure of an efficient induction of micronuclei after chlorpropham $(10 \mu \mathrm{M})$ and cytochalasin-B $(20 \mu \mathrm{M})$ seedlings treatment with subsequent microprotoplasts isolation. This technique is discussed for the transfer of alien chromosomes and genes from finger millet by microprotoplast-mediated chromosome transfer.
\end{abstract}

\section{Introduction}

Techniques of plant biotechnology have emerged as an important aid to the traditional breeding methods for rapid genetic improvement and for integration of new genes into existing crop varieties. Success with the cell culture establishment in vitro and plant regeneration for most of the cereal and grass species has given impetus for further work with less researched crop species, especially millets which are of immense importance for solving the food and forage problems for many countries. Millets are important because they are grown in poor soils with limited inputs and they constitute a major source of food for resource-poor farmers of the areas of their cultivation [1]. The projected food demand for 2025 [2] will require the yield of millets to rise from 2.5 to $4.5 \mathrm{tha}^{-1}$. Such yield increase could be largely achieved from improved varieties transgenically modified for biotic and abiotic stress resistance using different biotechnological methods [1].

Among various millets, finger millet Eleusine coracana (L.) Gaerth. is one of the well-known species for its outstanding properties as a subsistence food and forage crop [1]. Finger millet is a major crop in the arid and semiarid regions of developing countries of Asia and Africa; more small areas of it are also present in the Americas, Oceania, and Europe. Moreover, recently the new cultivars of E. coracana adapted to temperate climate zone have been bred in Ukraine [35]. It is planned to widely use this new perspective crop as additional very productive and economically advantageous source for forage and seed production, as well as alternative grass source for bioethanol production in countries with temperate climate of Eastern Europe.

The elaboration of effective protocols for in vitro cell culture production, plant regeneration, and protoplasts isolation will be the first step towards the biotechnology for improvement of this species by genetic transformation. The previous reports on E. coracana dealt only with regeneration of plants through organogenesis, multiple shoot production, and somatic embryogenesis [6-9], and these data are summarized in several reviews $[1,10,11]$. The attempts also have been made to establish gene transfer system for finger millet [12-17]. Moreover, up till now there was no obvious information about isolation and regeneration of protoplasts from 
finger millet that can be used for different cell and genetic engineering manipulations, including effective methods of microprotoplast-mediated chromosome transfer (MMCT) in interspecific or intergeneric breeding [18].

The present communication proposes an advanced and rapid method of plant regeneration through seedling callus cultures of E. coracana (L.) Gaerth. Here we also present an effective procedure of protoplast isolation and an efficient induction of micronuclei with subsequent microprotoplast isolation of finger millet. This technique is discussed for the transfer of alien chromosomes and genes from finger millet by MMCT.

\section{Materials and Methods}

Seeds of finger millet Eleusine coracana (L.) Gaerth. were surface-sterilized with $70 \%(\mathrm{v} / \mathrm{v})$ alcohol for $10 \mathrm{~min}$ followed by $5 \%(\mathrm{v} / \mathrm{v})$ sodium hypochlorite for $15 \mathrm{~min}$ twice. After rinsed for four times with sterile distilled water, they were used for callus induction and seedling production.

2.1. Establishment of Callus Cultures. Callus induction medium was stepwise determined in the following way: (1) basal medium selection, (2) hormonal optimization, and (3) supplements refining. Five different basal media were tested in step 1: media for callus initiation from $E$. coracana (MS macro- and microsalts, MS vitamins, $1 \mathrm{mg} \mathrm{L}^{-1}$ 2.4-dichlorphenoxy acetic acid, and 2.4-D, 3\% sucrose) [19]; medium for Setaria italica $\left(\mathrm{N}_{6}\right.$ macro- and microsalts, $\mathrm{N}_{6}$ vitamins, $200 \mathrm{mg} \mathrm{L}^{-1}$ casein hydrolysate, $2 \mathrm{mg} \mathrm{L}^{-1} 2.4-\mathrm{D}$, and 3\% sucrose) [20]; medium for Sorghum bicolor (MS macro- and microsalts, MS vitamins, $200 \mathrm{mg} \mathrm{L}^{-1}$ glutamine, $2 \mathrm{mg} \mathrm{L}^{-1} 2.4-\mathrm{D}$, and $2 \%$ sucrose) [21]; and media B and $\mathrm{E}$ for E. indica [22].

For callus induction several combinations of phytohormones of 2.4-D (1;2; $\left.3 \mathrm{mg} \mathrm{L}^{-1}\right)$, kinetin, KIN (0.2;0.4; 0.5 ; $\left.0.8 ; 1 \mathrm{mg} \mathrm{L}^{-1}\right)$, 1-naphthalene acetic acid, NAA $\left(1 ; 2 \mathrm{mg} \mathrm{L}^{-1}\right)$, and 6-benzylaminopurine, BAP $\left(0.2 ; 0.4 \mathrm{mg} \mathrm{L}^{-1}\right)$ supplemented to the best basal medium resulting from step 1 were tested in step 2 . In step 3, glutamine $\left(100 \mathrm{mg} \mathrm{L}^{-1}\right)$, proline $\left(500 \mathrm{mg} \mathrm{L}^{-1}\right)$, thiamine $\mathrm{HCl}\left(10 \mathrm{mg} \mathrm{L}^{-1}\right)$, tryptophan $\left(200 \mathrm{mg} \mathrm{L}^{-1}\right)$, glycine $\left(3 \mathrm{mg} \mathrm{L}^{-1}\right)$, and metal salts $\mathrm{AgNO}_{3}$ $\left(10 \mathrm{mg} \mathrm{L}^{-1}\right)$ and $1 \mu \mathrm{M} \mathrm{CuSO}_{4} \cdot 5 \mathrm{H}_{2} \mathrm{O}\left(0.249 \mathrm{mg} \mathrm{L}^{-1}\right)$, as the commonly used ones for cereals, in five different combinations were tested as additional additives.

All media were solidified with $0.6 \%$ agar and were adjusted to $\mathrm{pH}$ 5.7-5.8 prior to autoclaving. Three dishes with 30 seeds each were used in each treatment. Each experiment was repeated for three times. Cultures were incubated for three weeks in darkness at $26 \pm 2^{\circ} \mathrm{C}$. The effectiveness of each tested medium was evaluated based on the size and morphology (color, surface structure, water content, and tissue density) of the resultant calli. Only calli exceeded 2$3 \mathrm{~mm}$ and more in size were scored.

2.2. Plant Regeneration. Organogenesis from callus was induced via alteration in medium hormonal concentrations.
TABLE 1: Compositions of enzyme solutions used for E. coracana protoplasts isolation.

\begin{tabular}{lccccccc}
\hline \multirow{2}{*}{ Enzymes, in \% } & \multicolumn{7}{c}{ Variants of solutions } \\
& 1 & 2 & 3 & 4 & 5 & 6 & 7 \\
\hline Cellulase "Onozuka" R-10 & 10 & 2 & 1 & 1 & 2 & 2 & 1.5 \\
Drisellase & - & - & - & 0.5 & - & 0.5 & 0.5 \\
Pectolyase & 1 & 0.2 & 1 & 1 & 0.5 & 1 & 1 \\
Macerosyme R-10 & - & - & 1 & 0.6 & 1 & 0.5 & - \\
Hemicellulase & - & - & 0.5 & 0.5 & 0.5 & 0.2 & 0.2 \\
\hline
\end{tabular}

However, for each callus, the supplement combination was unchanged from the step 3 of callus induction. Calli were incubated for three weeks on an MS [23] medium with $1.5 \mathrm{mg} \mathrm{L}^{-1} \mathrm{KIN}$ and $0.2 \mathrm{mg} \mathrm{L}^{-1} \mathrm{NAA}$ in light with $14 \mathrm{~h}$ photoperiod. The resultant shoots were grown into plantlets in a basal (hormone-free) MS medium into $100 \mathrm{~mL}$ tubes with perlite under light incubation. Plants with well-developed root were transferred into small pots containing sterile soil and covered with glass caps, and then they were transferred to the field after two-three weeks of growth.

2.3. Protoplast Isolation. Both callus tissues and explants of seedlings (coleoptiles and mesocotyles) from 6-day-old seedlings were used in protoplast isolation. To select the most optimal conditions the tissues were first cut and digested in seven different enzyme combination solutions (Table 1) dissolved in four different osmotic media: (1) CPW [24]; (2) medium for of isolation protoplasts of E. indica [22]; (3) $10 \mathrm{x}$ $\mathrm{N}_{6}$ medium [25] + $80 \mathrm{mM} \mathrm{KCl,} 100 \mathrm{mM}$ mannitol ( $\mathrm{pH} 5.5$ ); (4) $0.6 \mathrm{mM}$ mannitol $+80 \mathrm{mM} \mathrm{CaCl}_{2}$ (pH 5.5). Tissues were digested at $25^{\circ} \mathrm{C}$ for $18-24 \mathrm{hrs}$. Protoplasts were purified using the following steps.

(1) Filter the enzyme solution into a centrifuge tube through a $60-70 \mu \mathrm{m}$ sterile nylon mesh. The debris on the mesh was washed with 3-4 $\mathrm{mL}$ of washing solution (155 mM NaCl; $30 \mathrm{mM} \mathrm{KCl} ; 5 \mathrm{mM} \mathrm{CaCl}_{2}$; and $15 \mathrm{mM}$ glucose) to flush down trapped protoplasts.

(2) Protoplasts were pelleted by centrifuging at $1000 \mathrm{rpm}$ for $5 \mathrm{~min}$. After removing the supernatant, $2-3 \mathrm{~mL}$ of washing solution was added.

(3) Carefully layer the protoplast suspension onto the top of a $3-4 \mathrm{~mL}$ of $20 \%$ sucrose solution in a fresh centrifuge tube.

(4) A white band of protoplast was formed at the interface of the sucrose and washing solution layers after the tube was centrifuged at $1000 \mathrm{rpm}$ for $5 \mathrm{~min}$.

(5) The protoplast band was pipetted out and diluted to 5-10 $\mathrm{mL}$ in volume with the washing solution for cell counting.

The purified protoplasts were cultured for 20-25 days in darkness at $25^{\circ} \mathrm{C}$ in a KM8p [26] medium supplemented with glutamine $\left(100 \mathrm{mg} \mathrm{L}^{-1}\right)$, proline $\left(500 \mathrm{mg} \mathrm{L}^{-1}\right), 2.4-\mathrm{D}$ $\left(0.5 \mathrm{mg} \mathrm{L}^{-1}\right)$, and $\mathrm{KIN}\left(0.2 \mathrm{mg} \mathrm{L}^{-1}\right)$. The resultant cell aggregates were embedded in an agar medium made of $1: 1$ 


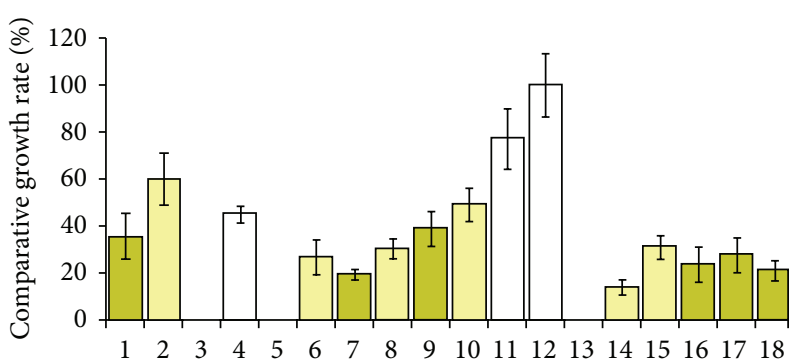

$\square$ White callus, compact, well structured, with sign of regenerative structures on the top

$\square$ Yellow (lemon) callus, less compact, globular, without sign of regeneration

$\square$ Yellow callus, watered, soft, nonviable

Variants of phytohormone concentrations $\left(\mathrm{mg} \mathrm{L}^{-1}\right)$ in medium:
(1) $1 \mathrm{D}$
(10) 2D; $0.4 \mathrm{KIN} ; 1 \mathrm{NAA}$
(2) $1 \mathrm{D} ; 0.2 \mathrm{KIN}$
(11) $2 \mathrm{D} ; 0.4 \mathrm{KIN} ; 2 \mathrm{NAA}$
(3) $1 \mathrm{D} ; 0.5 \mathrm{KIN}$
(12) $3 \mathrm{D}$
(4) $1 \mathrm{D} ; 0.5 \mathrm{KIN} ; 2 \mathrm{NAA}$
(13) 3D; $0.2 \mathrm{KIN}$
(5) $2 \mathrm{D}$
(14) $3 \mathrm{D} ; 0.6 \mathrm{KIN}$
(6) $2 \mathrm{D} ; 0.2 \mathrm{KIN}$
(15) 3D; 0.2 KIN; 0.4 BAP
(7) $2 \mathrm{D} ; 0.4 \mathrm{KIN}$
(16) $4 \mathrm{D}$
(8) $2 \mathrm{D} ; 0.8 \mathrm{KIN}$
(17) 4D; $0.4 \mathrm{KIN}$
(9) $2 \mathrm{D} ; 0.2 \mathrm{BAP}$
(18) $4 \mathrm{D} ; 1 \mathrm{KIN}$

FIGURE 1: Influence of different concentrations of auxins and cytokinins on E. coracana callus induction.

$(\mathrm{v} / \mathrm{v})$ ratio of a KM8p medium with the above supplements to a KM8p medium supplemented with glutamine $\left(200 \mathrm{mg} \mathrm{L}^{-1}\right)$, proline $\left(1000 \mathrm{mg} \mathrm{L}^{-1}\right)$, tryptophan $\left(200 \mathrm{mg} \mathrm{L}^{-1}\right)$, 2.4-D $\left(2 \mathrm{mg} \mathrm{L}^{-1}\right)$, zeatin $\left(0.4 \mathrm{mg} \mathrm{L}^{-1}\right)$, and agar $(1.2 \%)$. Cultures were incubated in darkness for 3-4 days before being transferred into light for further incubation and regeneration.

2.4. Micronucleation. Micronuclei were induced by the addition of 10-150 $\mu \mathrm{M}$ isopropyl $\mathrm{N}$-(3-chlorophenyl) carbamate, CIPC (chlorpropham) (Sigma, USA), and $20 \mu \mathrm{M}$ cytochalasin B (Sigma, USA) to $50 \mathrm{~mL}$ of liquid MS medium with $2 \mathrm{mg} \mathrm{L}^{-1}$ 2.4-D, $0.4 \mathrm{mg} \mathrm{L}^{-1} \mathrm{KIN}$, and $2 \mathrm{mg} \mathrm{L}^{-1}$ NAA where 3day-old seedlings were placed for subculture for $24 \mathrm{~h}$ at $25^{\circ} \mathrm{C}$ in the dark on a rotary shaker $(120 \mathrm{rpm})$. For microprotoplasts isolation $10 \mu \mathrm{M}$ CIPC and $20 \mu \mathrm{M}$ cytochalasin B were added also into enzyme solution 2 (Table 1 ) containing $80 \mathrm{mM}$ $\mathrm{CaCl}_{2}$ and $0.6 \mathrm{mM}$ mannitol as osmoticum to prevent the fusion of micronuclei and to disrupt microfilaments during protoplast isolation. The microprotoplasts were purified using the following steps: (i) we filtered the enzyme solution into a centrifuge tube through nylon mesh and washed with washing solution, as described earlier for protoplast isolation; (ii) pelleted microprotoplasts by centrifuging at $1000 \mathrm{rpm}$ for $5 \mathrm{~min}$; after removing the supernatant, 2-3 mL of washing solution was added; (iii) centrifuged at $1000 \mathrm{rpm}$ for 5 min to collect microprotoplasts then carefully removed the supernatant and added $3 \mathrm{~mL}$ KM8p medium supplemented with glutamine $\left(100 \mathrm{mg} \mathrm{L}^{-1}\right)$, proline $\left(500 \mathrm{mg} \mathrm{L}^{-1}\right), 2.4-\mathrm{D}$ $\left(0.5 \mathrm{mg} \mathrm{L}^{-1}\right)$, and $\mathrm{KIN}\left(0.2 \mathrm{mg} \mathrm{L}^{-1}\right)$.
For cytological analysis of microprotoplasts, $3 \mu \mathrm{g} \mathrm{mL}^{-1}$ 4, 6-diamodino-2-phenylindole (DAPI, Sigma, USA) was added to the suspension for $10 \mathrm{~min}$. The micronuclei were observed under luminescent microscope Axiostar plus (Carl Zeiss, Jena, Germany).

\section{Results and Discussion}

3.1. Establishment of Callus Cultures. Among the five culture media tested in step 1 of callus induction, only the Medium E supported healthy callus induction. The remaining media either failed to produce callus (Medium B) or resulted in small calli which soon became colorless and nonviable. Therefore, the basal components of Medium E [22], with $\mathrm{N}_{6}$ macrosalts, MS microsalts, and B5 organics [27], were chosen as the basal medium in the subsequent callus induction medium optimization tests.

Since 2.4-D is commonly considered as the most powerful callus induction hormone, it was included in all step 2 callus induction media tested. Figure 1 clearly showed that, after combined with other hormones, $2 \mathrm{mg} \mathrm{L}^{-1} 2.4-\mathrm{D}$ resulted in the highest, up to $100 \%$, callus formation percentages. While lower or higher 2.4-D concentrations resulted in significantly lower percentage of callus formation.

It is known that the addition of a small amount of cytokinin to the auxin-containing medium frequently inserts positive effects on callus induction. In this work, we found that the addition of an $0.2-0.6 \mathrm{mg} \mathrm{L}^{-1} \mathrm{KIN}$ always leads to a higher callus formation percentage over 2.4-D alone. Moreover KIN was also reported to have promotional effects on somatic embryogenesis of finger millet $[9,19]$. To compare the effectiveness of KIN versus BAP, $0.2 \mathrm{mg} \mathrm{L}^{-1}$ KIN was replaced by the same concentration of BAP in one case, and in another case $0.6 \mathrm{mg} \mathrm{L}^{-1} \mathrm{KIN}$ was substituted by $0.2 \mathrm{mg} \mathrm{L}^{-1} \mathrm{KIN}+0.4 \mathrm{mg} \mathrm{L}^{-1}$ BAP. The percentages of callus formation in both cases were clearly reduced. This suggested that, for E. coracana, KIN is a more effective cytokinin than BAP for callus induction. Similar results were reported by Pius et al. [19] for finger millet, although numerous reports indicated that BAP was preferred over KIN in induction of embryogenic calli of numerous cereal species [28].

There were three types of calli been observed in our works: (1) white, compact, well-structured callus; (2) yellow or lemon, less compact, globular callus; (3) yellow, watery, soft callus. It was found that the first type of callus (Figure 2(b)) was produced only when NAA was added to the $2.4 \mathrm{D}+$ KIN combinations. This type of callus was clearly superior in appearance compared to the remaining two types. It was also found that only the first type of callus stayed viable in the subsequent regeneration induction stage. Thus, despite that the NAA is not commonly used in cereal callus induction, we suggest that it is useful in light of callus regeneration capacity. This suggestion coincides with data of Kothari et al. [29] where NAA was added for plant regeneration of E. coracana from seeds used as initial explants.

We found also that there was no significant change in callus formation percentage regardless of the types of additional additive combinations tested supplemented to the basal media. 


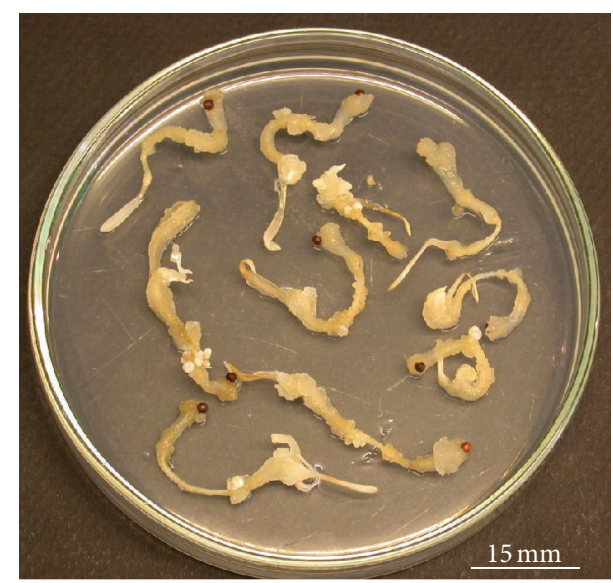

(a)

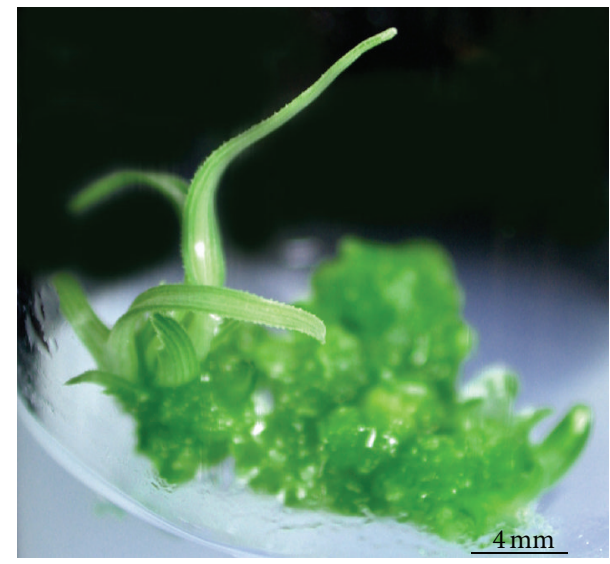

(c)

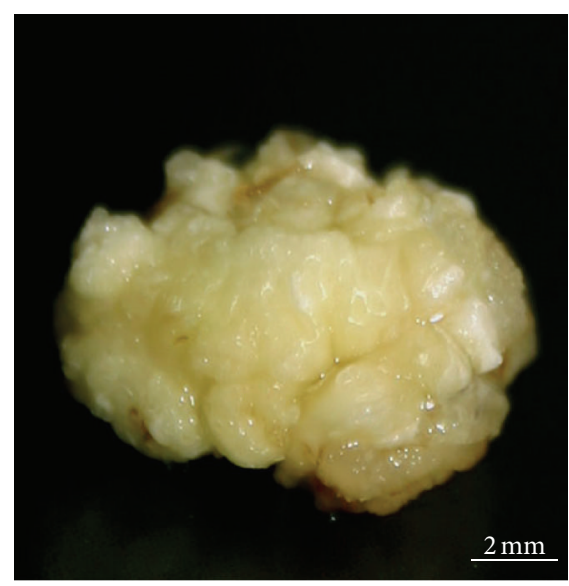

(b)

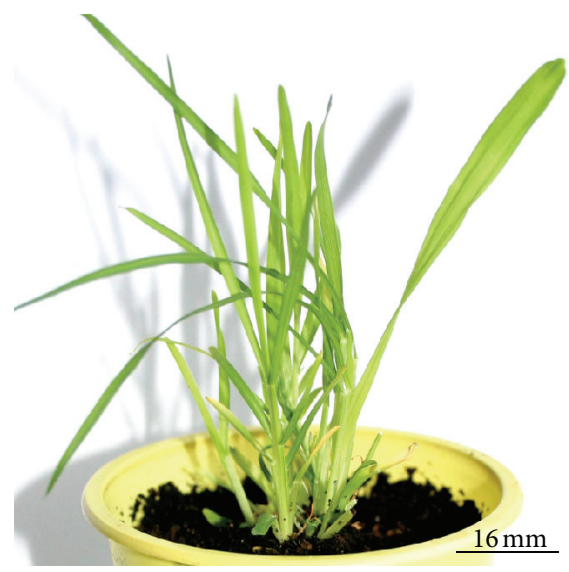

(d)

FIgURE 2: (a) Callus induction from mesocotyl of E. coracana from seed callus culture. (b) Morphology of compact, well-structured callus. (c) Plant regeneration of E. coracana from seed callus culture. (d) Rooted E. coracana plants in vitro.

3.2. Plant Regeneration. Although the percentage of callus formation was not affected by types of additives to the basal medium, different additive combinations greatly affected the quality of resultant tissues and resulted in significant differences in the final numbers of plantlets produced. Thus, we are presenting our results of this section in relation to the additives supplemented to the basal medium. It was found that the basal medium alone showed relatively low regeneration percentage and relatively poor tissue quality. The addition of glutamine and proline significantly improved such regeneration rate (Table 2) but failed to improve tissue quality. However, further supplementing of $\mathrm{AgNO}_{3}$ or $\mathrm{CuSO}_{4}$ cancelled out the advantage provided by glutamine and proline supplementation. This indicated possible toxic effects of such heavy metals.

Among the six supplementing treatments (Table 2), the supplementing of tryptophan only or supplementing of thiamine $\mathrm{HCl}$ and glycine in addition to glutamine and proline led to the highest percentages of regenerative calli. The resulting tissues of these two treatments appeared to have also the highest qualities and to be the most healthy. From healthyappearing regenerated shoots (Figure 2(c)), roots developed upon transferring to hormone-free medium. Regenerating
TABLE 2: Influence of different supplements on plant regeneration of E. coracana.

\begin{tabular}{|c|c|c|}
\hline Number & Supplements & $\begin{array}{l}\text { Number of regenerants per } \\
100 \text { explants }\end{array}$ \\
\hline 1 & - & 0 \\
\hline 2 & $\begin{array}{l}100 \mathrm{mg} \mathrm{L}^{-1} \text { glutamine } \\
500 \mathrm{mg} \mathrm{L}^{-1} \text { proline }\end{array}$ & $30 \pm 9.16$ \\
\hline 3 & $\begin{array}{c}100 \mathrm{mg} \mathrm{L}^{-1} \text { glutamine } \\
500 \mathrm{mg} \mathrm{L}^{-1} \text { proline } \\
10 \mathrm{mg} \mathrm{L}^{-1} \mathrm{AgNO}_{3}\end{array}$ & $25 \pm 8.66$ \\
\hline 4 & $\begin{array}{c}100 \mathrm{mg} \mathrm{L}^{-1} \text { glutamine } \\
500 \mathrm{mg} \mathrm{L}^{-1} \text { proline } \\
0,249 \mathrm{mg} \mathrm{L}^{-1} \mathrm{CuSO}_{4} \cdot 5 \mathrm{H}_{2} \mathrm{O}\end{array}$ & 0 \\
\hline 5 & $\begin{array}{c}100 \mathrm{mg} \mathrm{L}^{-1} \text { glutamine } \\
500 \mathrm{mg} \mathrm{L}^{-1} \text { proline } \\
10 \mathrm{mg} \mathrm{L}^{-1} \text { thiamine } \mathrm{HCl} \\
3 \mathrm{mg} \mathrm{L}^{-1} \text { glycine }\end{array}$ & $56 \pm 9.92$ \\
\hline 6 & $200 \mathrm{mg} \mathrm{L}^{-1}$ tryptophan & $45 \pm 9.94$ \\
\hline
\end{tabular}

shoots from the nonsupplemented control treatment were of poor quality and failed to produce viable plants. The 


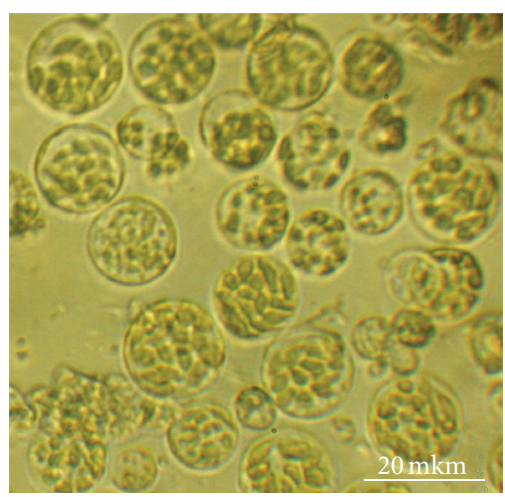

(a)

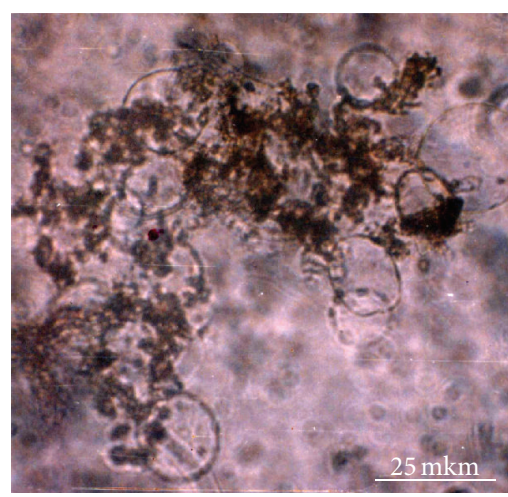

(b)

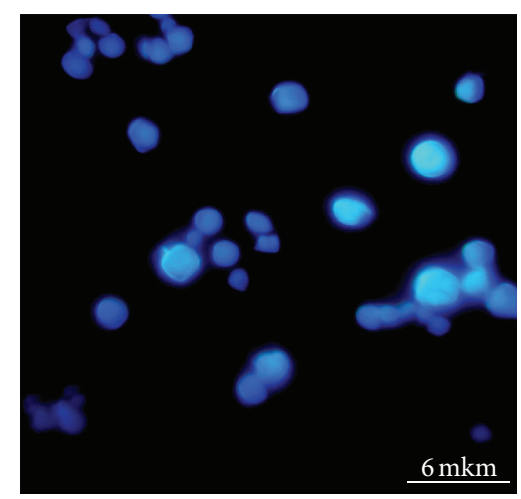

(c)

FIGURE 3: (a) E. coracana protoplasts isolated from seedlings. (b) Microcolonies formation in liquid KM8p medium. (c) Micronuclei in E. coracana cells.

supplementation of $\mathrm{CuSO}_{4}$ inhibited root formation and did not result in plant production either. Although the supplementing of only glutamine and proline or with $\mathrm{AgNO}_{3}$ in addition had high regeneration percentages, due to their poor tissue qualities (yellow calli with little compact structure), the number of viable plants formed was not high. In spite of their lowest regeneration percentages, treatments that led to good tissue qualities (white, well-structured calli) resulted in the highest number of viable plant production. These were treatments supplemented either with tryptophan alone or with thiamine $\mathrm{HCl}$ and glycine in addition to glutamine and proline.

Green and Philips [30] demonstrated that the supplementation of proline enhances somatic embryogenesis in maize, and Sirivardana and Nabros [31] showed that tryptophan favored somatic embryogenesis in some rice cultivars. Eapen and George [8], on the other hand, experienced decreased embryo germination frequency in finger millet when glutamine, proline, and tryptophan were supplemented. Thiamine was used by Chu et al. [25] to induce large quantity of cereal plant regenerants.

At the same time the supplementing of $\mathrm{CuSO}_{4}$ did not lead to positive effect in plant regeneration. These data agreed with that of Purnhauser and Gyulai [32] that $\mathrm{CuSO}_{4}$ supplementation inhibited rape regeneration. In contrast, $\mathrm{Cu}^{2+}$ enhanced rhizogenesis in barley cultures (up to 93.7\%) [33], wheat, and triticale [32]. Dahleen [34] also used $\mathrm{CuSO}_{4}$ to increase barley regeneration. The reason that led to the above discrepancy is not clear, and the role of copper in regeneration is not well understood. Since $\mathrm{Cu}^{2+}$ is the cofactor of many important enzymes in electron transport and protein/carbohydrate biosynthesis, Purnhauser and Gyulai [32] suggested the possibility that some of these enzymes might play certain roles in plant regeneration.

In conclusion, our results suggested that the number of plants (Figure 2(d)) eventually produced did not correlate directly with the regeneration percentage of the tissues; instead, it was closely associated with the quality of the tissues which were dictated by the hormones and supplements in the basal medium. From the obtained results, for future experiments we propose to use the following additional composition of media for callus induction and plant regeneration of finger millet: $100 \mathrm{mg} \mathrm{L}^{-1} \mathrm{Glu}, 500 \mathrm{mg} \mathrm{L}^{-1}$ Pro, $10 \mathrm{mg} \mathrm{L}^{-1}$ $\mathrm{B}_{1}$, and $3 \mathrm{mg} \mathrm{L}^{-1}$ Gly.

3.3. Protoplast Isolation and Culture. Among the four protoplast osmotic media, only Medium 4 supported viable protoplast isolation. Despite the CPW (Medium 1) being successful in supporting protoplast isolation for several cereal species, Poa pratensis [35], rice [36], and S. bicolor [37], its osmolarity was too low for E. coracana and led to the swelling of the isolated protoplasts that burst at the washing step. The same was true for Medium 3. Medium 2, on the other hand, had too high osmolarity and resulted in the condensation of all plastids at the center of the protoplasts.

Among the seven tested enzyme mixtures, Solution 2 supported the best protoplast isolation. Protoplasts resulting from this enzyme solution were spherical in shape, rich in cytoplasm, and void of large vacuoles. It was possible to reduce the time of digestion to 4 hrs.

Protoplast yield from callus was $1 \times 10^{4}$ protoplasts per gram of tissue; while the per-gram yield from seedling coleoptyle tissues was $5 \times 10^{6}$ protoplasts (Figure 3(a)). We feel that, for E. coracana, seedling explants resulted in sufficiently high protoplast yield upon enzyme digestion. Protoplasts started regenerating cell walls within 4-5 days in the supplemented KM8p liquid medium. Cell division took place 1-2 days later. Microcolonies (Figure 3(b)) were visible in 20-25-day-old cultures. Then they were embedded into solid KM8p medium for further plant regeneration. Thus, we described here for the first time the elaborated method of effective protoplast isolation from E. coracana, which could be used in future the in different programs on cellular engineering of millets, for example, through methods of symmetric or asymmetric somatic hybridization.

3.4. Micronucleation. Polygenic traits or traits with unknown biochemical or molecular mechanisms (e.g., resistance to certain diseases or stresses and other economically important traits) are still recalcitrant to transfer using methods 
of genetic engineering. Recently, an alternative asymmetric somatic hybridization method using microprotoplasts (microprotoplast fusion) has been developed [18]. Since microprotoplasts contain only one or a few intact chromosomes, a limited number of chromosomes can be transferred via microprotoplast fusion, resulting in the production of chromosome addition lines with even a single and specific intact chromosome between sexually incompatible species $[18,38]$. In order to apply this technique for improvement of monocot plant species, we established an efficient system for mass-preparation of microprotoplasts of E. coracana. Here, we present an effective method of the induction by antimitotic agents and isolation of microprotoplast from finger millet somatic cells. As antimitotic drugs $10-150 \mu \mathrm{M}$ CIPC and $20 \mu \mathrm{M}$ cytochalasin B were used for micronuclei induction in cells of finger millet seedling. Different concentration of CIPC and $20 \mu \mathrm{M}$ cytochalasin B were added to liquid MS medium supplemented with $2 \mathrm{mg} \mathrm{L}^{-1} 2.4-\mathrm{D}$, $0.4 \mathrm{mg} \mathrm{L}^{-1} \mathrm{KIN}$, and $2 \mathrm{mg} \mathrm{L}^{-1} \mathrm{NAA}$ where 3 -day-old seedlings were placed for subcultivation for $24 \mathrm{~h}$ at $25^{\circ} \mathrm{C}$ in the dark on a rotary shaker. For microprotoplasts isolation both drugs were added also into enzyme solution to prevent the fusion of micronuclei and to disrupt microfilaments during protoplast isolation. It has been found that the most effective concentration of CIPC was $10 \mu \mathrm{M}$, which in combination with $20 \mu \mathrm{M}$ cytochalasin $\mathrm{B}$ led to the highest percentage of micronuclei formation (Figure 3(c)). As a rule the cells with 3-4 micronuclei were observed after such treatment of finger millet cells. It is corresponding to the previously obtained data where CIPC in this concentration was successfully used to obtain microprotoplasts from developing microspores of lily species [38]. The system described here can be used for the transfer of one or a few chromosomes via microprotoplast fusion from finger millet to different economically important grasses or cereals. Because it is known that finger millet is little affected by disease and insects [39]. Chromosome addition lines produced via such technique may contribute to genetic improvement of the above-mentioned plant species.

\section{Conflict of Interests}

None of the authors has a conflict of interests with any mentioned commercial identity in the paper.

\section{Acknowledgment}

The authors wish to express their thanks to Professor Emeritus C. Hu (Wm. Paterson University of New Jersey, USA) for critical evaluation of the paper and improvement of its English version.

\section{References}

[1] S. L. Kothari, S. Kumar, R. K. Vishnoi, A. Kothari, and K. N. Watanabe, "Applications of biotechnology for improvement of millet crops: review of progress and future prospects," Plant Biotechnology, vol. 22, no. 2, pp. 81-88, 2005.
[2] N. E. Borlaug, "Feeding a world of 10 billion people: the miracle ahead," In Vitro Cellular and Developmental Biology -Plant, vol. 38, no. 2, pp. 221-228, 2002.

[3] N. O. Stadnichuk and A. A. Abramov, "Finger millet (Eleusine coracana (L.) Gaertn.), variety 'Tropikanka”, Ukrainian plant variety certificate No. 1252, State Service for Plant Variety Protection (invention No. 9950001 from 12. 12. 1999), 2001.

[4] N. O. Stadnichuk, G. Y. Bayer, A. I. Yemets, D. B. Rakhmetov, and B. Y. Blume, "Finger millet (Eleusine coracana (L.) Gaertn.), variety 'Yaroslav-8,' Ukrainian plant variety certificate No. 09551, State Service for Plant Variety Protection (invention No. 03.11.2008), 2009.

[5] N. O. Stadnichuk, A. I. Yemets, D. B. Rakhmetov, and B. Y. Blume, "Finger millet (Eleusine coracana (L.) Gaertn.), variety 'Yevgeniya,' Ukrainian plant variety certificate No. 120109, State Service for Plant Variety Protection ( invention No. 10344001 from 03.11.2010), 2011.

[6] T. Wakizuka and T. Yamaguchi, "The induction of enlarged apical domes in vitro and multi-shoot formation from finger millet (Eleusine coracana)," Annals of Botany, vol. 60, no. 3, pp. 331-336, 1987.

[7] S. Eapen and L. George, "High frequency plant regeneration through somatic embryogenesis in finger millet (Eleusine coracana Gaertn)," Plant Science, vol. 61, no. 1, pp. 127-130, 1989.

[8] S. Eapen and L. George, "Influence of phytohormones, carbohydrates, aminoacids, growth supplements and antibiotics on somatic embryogenesis and plant differentiation in finger millet," Plant Cell, Tissue and Organ Culture, vol. 22, no. 2, pp. 87-93, 1990.

[9] P. Sivadas, S. L. Kothari, and N. Chandra, "High frequency embryoid and plantlet formation from tissue cultures of the Finger millet-Eleusine coracana (L.) Gaertn," Plant Cell Reports, vol. 9, no. 2, pp. 93-96, 1990.

[10] V. D. Reddy, K. V. Rao, T. P. Reddy, and P. B. K. Kishor, "Finger millet," in Compendium of Transgenic Crop Plants: Transgenic Cereals and Forage Grasses, C. Kole and T. C. Hall, Eds., pp. 191198, Blackwell, London, UK, 2008.

[11] S. A. Ceasar and S. Ignacimuthu, "Genetic engineering of millets: current status and future prospects," Biotechnology Letters, vol. 31, no. 6, pp. 779-788, 2009.

[12] P. Gupta, S. Raghuvanshi, and A. K. Tyagi, "Assessment of the efficiency of various gene promoters via biolistics in leaf and regenerating seed callus of millets, Eleusine coracana and Echinochloa crusgalli," Plant Biotechnology, vol. 18, no. 4, pp. 275-282, 2001.

[13] A. M. Latha, K. V. Rao, and V. D. Reddy, "Production of transgenic plants resistant to leaf blast disease in finger millet (Eleusine coracana (L.) Gaertn.)," Plant Science, vol. 169, no. 4, pp. 657-667, 2005.

[14] S. Mahalakshmi, G. S. B. Christopher, T. P. Reddy, K. V. Rao, and V. D. Reddy, "Isolation of a cDNA clone (PcSrp) encoding serine-rich-protein from Porteresia coarctata T. and its expression in yeast and finger millet (Eleusine coracana L.) affording salt tolerance," Planta, vol. 224, no. 2, pp. 347-359, 2006.

[15] A. Yemets, V. Radchuk, O. Bayer et al., "Development of transformation vectors based upon a modified plant $\alpha$-tubulin gene as the selectable marker," Cell Biology International, vol. 32, no. 5, pp. 566-570, 2008.

[16] S. A. Ceasar and S. Ignacimuthu, "Agrobacterium-mediated transformation of finger millet (Eleusine coracana (L.) Gaertn.) 
using shoot apex explants," Plant Cell Reports, vol. 30, no. 9, pp. 1759-1770, 2011.

[17] M. Sharma, A. Kothari-Chajer, S. Jagga-Chugh, and S. L. Kothari, "Factors influencing Agrobacterium tumefaciens-mediated genetic transformation of Eleusine coracana (L.) Gaertn," Plant Cell, Tissue and Organ Culture, vol. 105, no. 1, pp. 93-104, 2011.

[18] A. I. Yemets and B. Y. Blume, "Antimitotic drugs for microprotoplast-mediated chromosome transfer in plant genomics, cell engineering and breeding," in The Plant Cytoskeleton: Genomic and Bioinformatic Tools for Biotechnology and Agriculture, Y. B. Blume, W. V. Baird, A. I. Yemets, and D. Breviario, Eds., pp. 435-454, Springer, Berlin, Germany, 2008.

[19] J. Pius, L. George, S. Eapen, and P. S. Rao, "Influence of genotype and phytohormones on somatic embryogenesis and plant regeneration in finger millet," Proceedings of the Indian National Science Academy, vol. 60, pp. 53-56, 1994.

[20] T. G. Lu and C. S. Sun, "Cryopreservation of foxtail millet (Setaria italica L.)," Biotechnology in Agriculture and Forestry, vol. 98, pp. 1099-1103, 1995.

[21] A. M. Rao, K. P. Sree, and P. B. K. Kishor, "Enhanced plant regeneration in grain and sweet sorghum by asparagine, proline and cefotaxime," Plant Cell Reports, vol. 15, no. 1-2, pp. 72-75, 1995.

[22] A. I. Yemets, L. A. Klimkina, L. V. Tarassenko, and Y. B. Blume, "Efficient callus formation and plant regeneration of goosegrass [Eleusine indica (L.) Gaertn.]," Plant Cell Reports, vol. 21, no. 6, pp. 503-510, 2003.

[23] T. Murashige and F. Skoog, "A revised medium for rapid growth and bioassays with tobacco tissue culture," Physiologia Plantarum, vol. 15, pp. 473-497, 1962.

[24] E. C. Cocking and J. F. Peberdy, The Use Protoplasts from Fungi and Higher Plants as Genetic Systems, Department of Botany, University of Nottingham, Nottingham, UK, 1974.

[25] C. C. Chu, C. C. Wang, C. S. Sun et al., "Establishment of an efficient medium for anther culture of rice through comparative experiments on the nitrogen sources," Scientia Sinica, vol. 18, pp. 659-668, 1975.

[26] K. N. Kao and M. R. Michayluk, "Nutritional requirements for growth of Vicia hajastana cells and protoplasts at a very low population density in liquid media," Planta, vol. 126, no. 2, pp. 105-110, 1975.

[27] O. L. Gamborg, R. A. Miller, and K. Ojima, "Nutrient requirements of suspension cultures of soybean root cells," Experimental Cell Research, vol. 50, no. 1, pp. 151-158, 1968.

[28] J. Patnaik, S. Sahoo, and B. K. Debata, "Somatic embryogenesis and plantlet regeneration from cell suspension cultures of palmarosa grass (Cymbopogon martinii)," Plant Cell Reports, vol. 16, no. 6, pp. 430-434, 1997.

[29] S. L. Kothari, K. Agarwal, and S. Kumar, "Inorganic nutrient manipulation for highly improved in vitro plant regeneration in finger millet-Eleusine coracana (L.) Gaertn," In Vitro Cellular and Developmental Biology-Plant, vol. 40, no. 5, pp. 515-519, 2004.

[30] C. E. Green and R. L. Phillips, "Plant regeneration from tissue cultures of maize," Crop Science, vol. 15, pp. 417-421, 1998.

[31] S. Siriwardana and M. W. Nabors, "Tryptophan enhancement of somatic embryogenesis in rice," Plant Physiology, vol. 73, pp. 143-146, 1983.

[32] L. Purnhauser and G. Gyulai, "Effect of copper on shoot and root regeneration in wheat, triticale, rape and tobacco tissue cultures," Plant Cell, Tissue and Organ Culture, vol. 35, no. 2, pp. 131-139, 1993.
[33] A. M. Castillo, B. Egaña, J. M. Sanz, and L. Cistué, "Somatic embryogenesis and plant regeneration from barley cultivars grown in Spain," Plant Cell Reports, vol. 17, no. 11, pp. 902-906, 1998.

[34] L. S. Dahleen, "Improved plant regeneration from barley callus cultures by increased copper levels," Plant Cell, Tissue and Organ Culture, vol. 43, no. 3, pp. 267-269, 1995.

[35] K. A. Nielsen, E. Larsen, and E. Knudsen, "Regeneration of protoplast-derived green plants of Kentucky blue grass (Poa pratensis L.)," Plant Cell Reports, vol. 12, no. 10, pp. 537-540, 1993.

[36] Z. S. Zhang Shiping, "Efficient plant regeneration from Indica (group 1) rice protoplasts of one advanced breeding line and three varieties," Plant Cell Reports, vol. 15, no. 1-2, pp. 68-71, 1995.

[37] R. V. Sairam, N. Seetharama, P. S. Devi, A. Verma, U. R. Murthy, and I. Potrykus, "Culture and regeneration of mesophyllderived protoplasts of sorghum [Sorghum bicolor (L.) Moench]," Plant Cell Reports, vol. 18, no. 12, pp. 972-977, 1999.

[38] H. Saito and M. Nakano, "Preparation of microprotoplasts for partial genome transfer via microprotoplast fusion in Liliaceous ornamental plants," Japan Agricultural Research Quarterly, vol. 36, no. 3, pp. 129-135, 2002.

[39] S. Neves, "Eleusine," in Wild Crop Relatives: Genomic and Breeding Resources, Millets and Grasses, C. Kole, Ed., pp. 113-133, Springer, Berlin, Germany, 2011. 

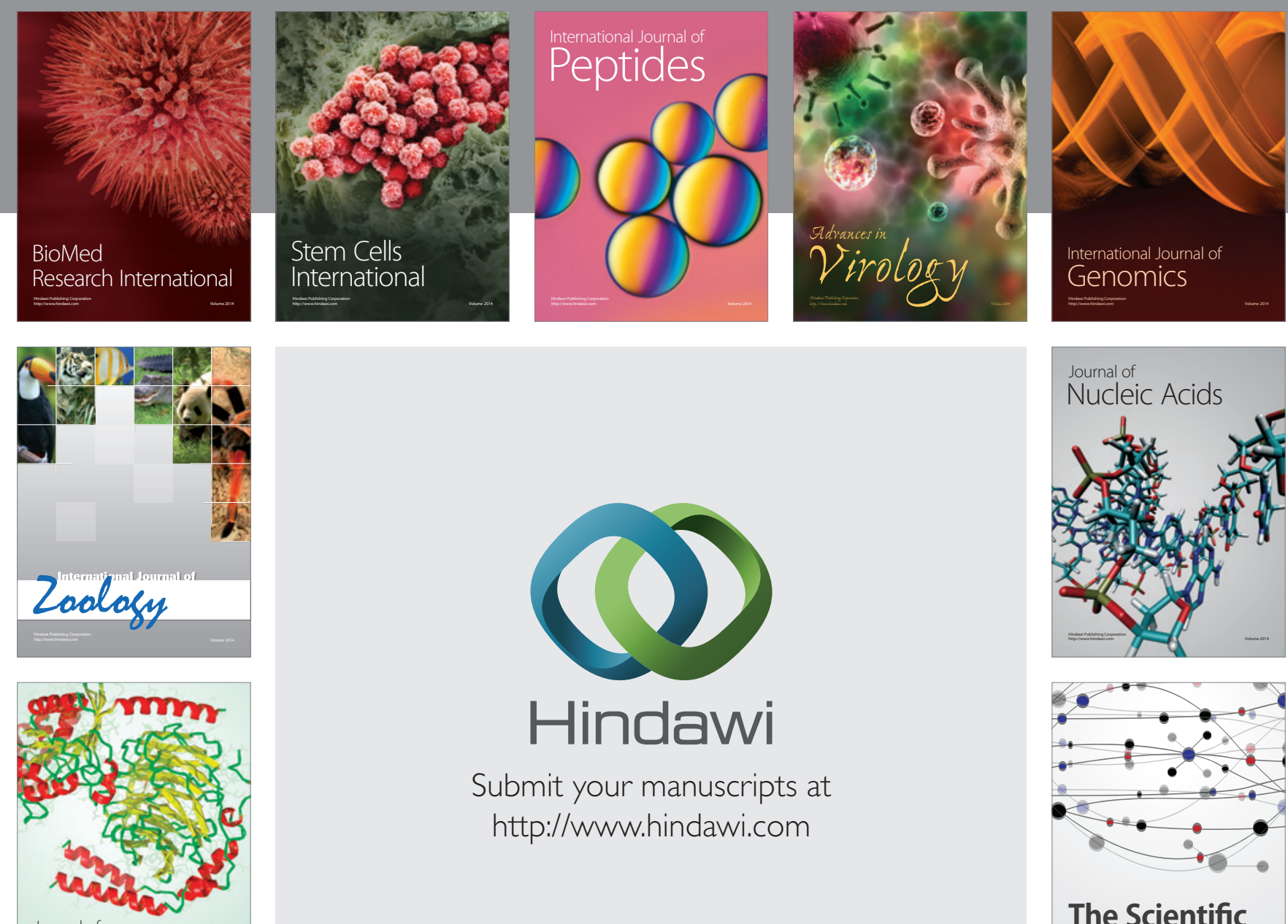

Submit your manuscripts at

http://www.hindawi.com

Journal of
Signal Transduction
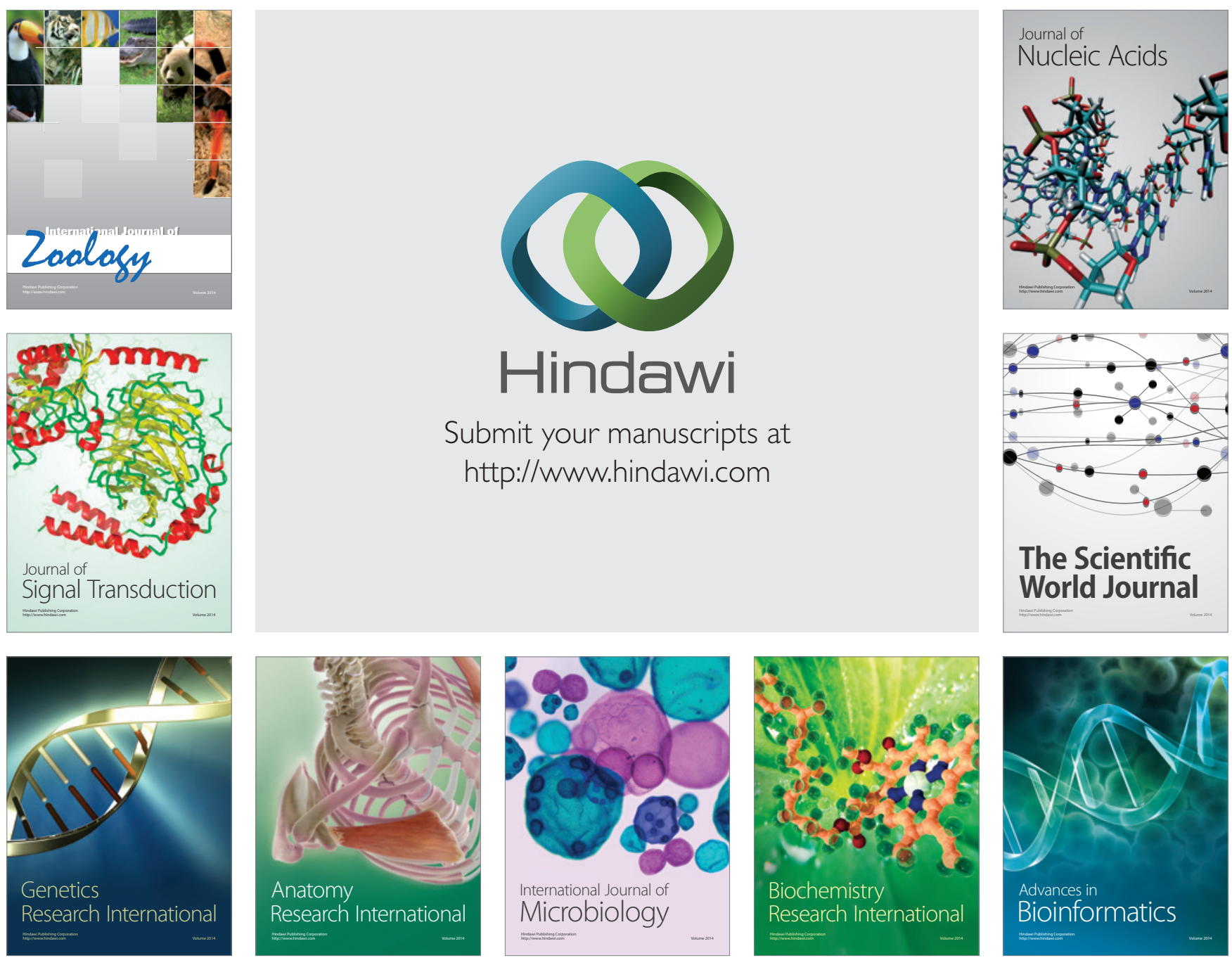

The Scientific World Journal
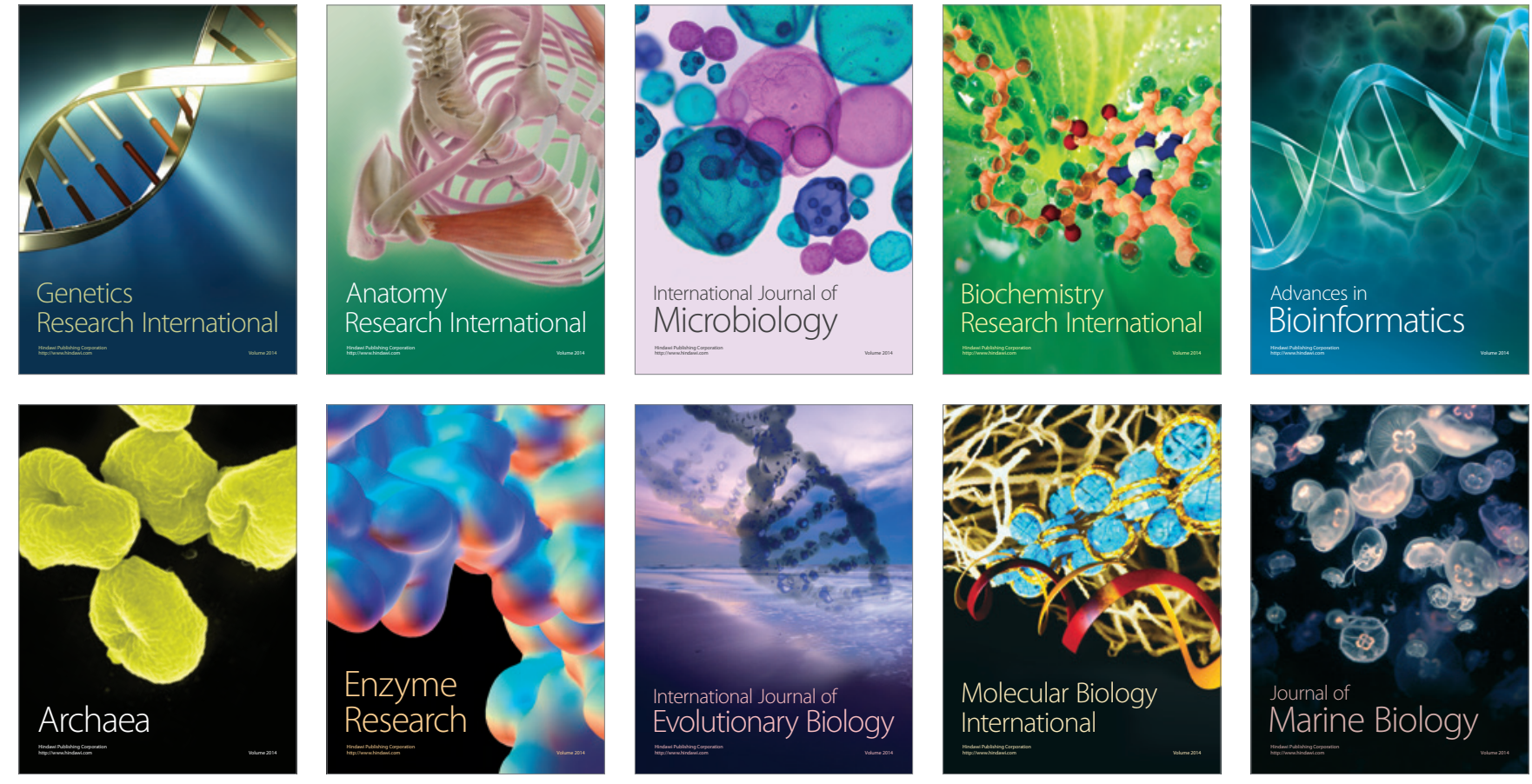